\title{
Public and Press Rights of Access to Prisoners
}

\section{After Branzburg and Mandel}

The internal administration of American prisons has often been shrouded from public view. ${ }^{1}$ In part, such invisibility has resulted from prison rules which limit communication between prisoners and those on the "outside."2 Suits alleging that such rules violate freedom of expression have enjoyed increasing success as courts have extended at least partial coverage of the First Amendment to prisoners. ${ }^{3}$ Three recent federal decisions have gone a step farther and held that rules that interfere with communication between prisoners and reporters may violate not only the prisoners' First Amendment rights but those of reporters and the public as well.* The full impact of this new line of cases must be assessed, however, in light of the Supreme Court's subsequent denial of testimonial immunity to reporters in Branzburg $v$. Hayes ${ }^{5}$ and its effective evisceration of any First Amendment "public right to hear" in Kleindienst v. Mandel. ${ }^{\circ}$ Although Branzburg and

1. New York State Special Commission on Attica, Official Report xii (1971). The Attica Commission concluded that, "The worrisome reality is that prisons, prisoners, and problems of both are essentially invisible in the United States. We Americans have made our prisons disappear from sight as if by act of will." Id.

2. Another factor which limits communication is that American prisons are often located in remote rural areas. For example, the Attica Commission found that the geographic isolation of Attica rendered the right of prisoners to receive visitors "illusory" since many of the inmates' families and friends could not afford transportation to the prison or lodging after they arrived. NEw YORK STATE SPECIal Comassion on ATrica, supra note 1 , at 61 .

3. Lower courts have found that a number of First Amendment rights, including those of expression, survive incarceration. See, e.g., Sostre v. MIcGinnis, 442 F2d 178, 202-03 (2d Cir. 1971) (right to possess one's own writings), cert. denied, 404 U.S. 1049 (1972); Brown v. Peyton, 437 F.2d 1228, 1231 -32 (4th Cir. 1971) (right to reccive religious literature); Walker v. Blackwell, 411 F.2d 23, 28.29 (5th Cir. 1969) (right to receive religious literature and correspond with religious leaders); Jackson v. Godwin. 400 F.2d 529, $540-42$ (5th Cir. 1968) (right to receive Black publications); Payne v. Whitmore, 325 F. Supp. 1191, 1193 (N.D. Cal. 1971) (right to receive newspapers and magazines); Fortune Society v. McGinnis, 319 F. Supp. 901,905 (S.D.N.Y. 1970) (right to rective a nevisletter published by former inmates and often critical of prison authorities); Paimigiano $v$. Travisono, 317 F. Supp. 776, 791 (D.R.I. 1970) (right to send uncensored, uninspected mail); Carothers v. Follette, 314 F. Supp. 1014, I023-26 (S.D.N.Y. 1970) (right to send one's family a letter critical of prison officials). But see Labat v. MIckeithen, 361 F.2d 757 (5th Cir. 1966) (blanket ban on letters sent by death-row inmate is reasonable); Lee v. Tahash, 352 F.2d 970 (8th Cir. 1965) (prison restrictions on extent and character of prisoner correspondence do not infringe First Amendment). See also Note, Prison Mail Censorship and the First Amendment, 81 Y.ALE L.J. 87 (1971); Note, The Right of Expression in Prison, 40 S. CAL. L. REv. 407 (1967); 18 GAtiolic U. L. REv. 237 (1963). For recent cases vindicating prisoner expression rights, see note 16 infra.

4. Nolan v. Fitzpatrick, 451 F.2d 545 (lst Cir. 1971); Washington Post Co. v. Klcindienst, Civil No. 467-72 (D.D.C., Apr. 5, 1972), I PRIsoN L. RmR. 141 (1972) (For a detailed history of this decision, see note 24 infra); Burnham v. Osiald, 342 F. Supp. 880 (W.D.N.Y. 1972).

5. 408 U.S. 665 (1972).

6. 408 U.S. 753 (1972). 
Mandel do not undermine the holdings of the three prison decisions, their doctrinal overtones cast serious doubt on the existence of any special First Amendment privilege for reporters seeking access to prisoners.

\section{Breaches in the Wall of Silence: Recent Decisions on Press Access to Prisoners}

Typical prison rules and procedures limiting communication between inmates and persons outside the prison include restrictions on the type of manuscripts prisoners may publish, ${ }^{7}$ bans on letters to all but approved correspondents, ${ }^{8}$ mail censorship, ${ }^{0}$ limitations on the number and type of visitors a prisoner may have, ${ }^{10}$ and bans on prisoner inter-

7. See, e.g., Bureau of Prisons, U.S. Dep't of Justice, Policy Statement 7300.7A, In* mate Manuscripts, July 7,1971 , which provides that an inmate manuscript

shall not be approved for publication if it deals with the life or criminal carcer

of the writer or any other person, matters presently in litigation, or if the publi.

cation contains statements that are likely to have a detrimental effect on security or discipline.

8. See, e.g., Bureau of Prisons, U.S. Dep't of Justice, Policy Statement 7300.1A, Correspondence Regulations 2, March 16, 1972. Prior approval of correspondents is gen. erally not required under these regulations. However, an inmate may be placed on "re. stricted correspondence" status if he mails an excessive number of letters, regularly at. tempts to correspond with persons unknown to him except through ads in newspapers and magazines, id. at 1 , or mails letters which are frequently rejected for any of several reasons, including the fact that they contain discussions of criminal activities. Id. at 4. Administrative approval of correspondents is required for inmates on restricted status. Id. at 2. Other permissible reasons for requiring prior approval include inmates' status as "major security risks, major participants in organized criminal activities ... [or] notorious or highly publicized offenders." Id. at 2. The Danbury, Conn., Fecleril Correctional Institution, Policy Statement CT-7300.15, March 24, 1972, which imple. ments the Federal Policy Statement on inmate correspondence, provides that an inmato may be placed on restricted correspondence status if his letters "jeopardize community relations." Id. at 2.

9. See, e.g., Bureau of Prisons, U.S. Dep't of Justice, Policy Statement 7300.1A, CorIespondence Regulations 4, March 16, 1972. That Statement provides that inmate letters will not be forwarded if they contain (1) material which might violate postal regulations, such as threats or blackmail, (2) discussions of criminal activities, (3) instructions for the operation of the inmate's former business, (4) code messages, or (5) language other than English. The fifth condition is not, however, a complete ban on non-English letters since efforts are made to accommodate inmates who are unable to write in English. $I d$. The Danbury, Conn., Federal Correctional Institution, Policy Statement CT.7300.15, March 24, 1972, supra note 8, also proscribes inmate letters which solicit "catalogucs, unauthorized educational material, price lists, unauthorized newspapers, printed mat. terial, free samples, etc." Id. at 6.

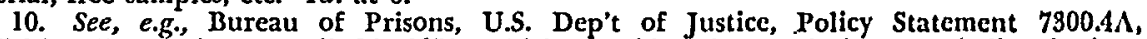
Visiting Regulations, April 24, 1972, which provides that each inmate shall submit a list of persons with whom he wishes to visit. Id. at 6. Proposed visitors will then be investigated for clearance by prison officials. Members of an inmate's immediatc family will be approved as visitors "under ordinary circumstances." Id. at 3. Other relatives may be placed on the list. Friends may be approved as visitors "if it can be ascertained that the association or friendship is a genuinely constructive one and that the offender would profit from such continued contact." Id. After approval of the visitor list, re. strictions may be placed on the number who may visit at any one time and the fre. quency of visits. Id. at 2, 3. Danbury, Conn., Federal Correctional Institution, Policy Statement CT-7300.18, May 26, 1972, implementing this visitation policy, provides that "each inmate will be allotted seven visits per calendar month" and that "the number of persons visiting one inmate as a group shall be limited to three." Id. at 5 . 
views by reporters. ${ }^{11}$ Despite the fact that they clearly restrict prisoner expression, such rules have been upheld as a proper exercise of administrative discretion to achieve prison security and other objectives of incarceration. ${ }^{12}$ The assumption that prisoners forfeited most expression rights eliminated the otherwise obvious requirement that such rules meet First Amendment standards. ${ }^{13}$ This assumption, however, was seriously undermined by the Supreme Court's 1964 decision in Cooper v. Pate ${ }^{14}$ that prison restrictions on religious practices were subject to the First Amendment. ${ }^{15}$ Subsequent decisions in lower courts have enlarged the scope of protected prisoner rights, ${ }^{16}$ but no court has yet

11. See, e.g., Bureau of Prisons, U.S. Dep't of Justice, Policy Statement 1220.1.1. Inmate Correspondence with Representatives of the Press and News Mfedia, Feb. I1. 1972, which states that "press representatives will not be permitted to intervici" individual inmates." This interview ban was struck down in The Washington Post Co. $v$. Kleindienst, Civil No. 467-72 (D.D.C., Apr. 5, 1972), I Prisox L. Rirm. I4l (1972). For a detailed history of this decision, see note 24 infra.

Rather than banning interviews completely, other prison rules may allow them only at the discretion of the prison administrator. In Burnham v. Oswald, 342 F. Supp. 880 (W.D.N.Y. 1972), the court voided a New York rule which allowed prison officials to deny interviews which would "adversely affect the integrity, security and safety of correctional programs and facilities, and inmates or parolees thereof." But sec SeattleTacoma Newspaper Guild v. Daggett, Civil No. 9557 (W.D. W'ash., May 6, 1972), 1 PRISON L. RPTR. 229 (1972) (upholding an interview restriction at a federal institution).

The National Council on Crime and Delinquency, in a proposed model act to protect prisoners' rights, would permit interviewing of prisoners by reporters. 18 CRIssE \& DEinquency 13 (1972). See also New York State Stechl Comsissios on ATtiat, supra note 1 , at 63 .

12. See, e.g., Berrigan v. Norton, 322 F. Supp. 46, 50.5l (D. Conn. 197l), af/d, 451 F.2d 790 (2d Cir. 1971).

13. Without such conceptual underpinning, this "hands ofr" doctrine would be contrary to a celebrated line of cases in other contexts vindicating First Amendment rights infringed by administrative rules or actions. See, e.g., Shuttlesworth s. City of Birmingham, 394 U.S. 147 (1969); Staub v. City of Baxley, 355 U.S. 313 (1958). The doctrine has been frequently criticized. See, e.g., Goldfarb and Singer, Redressing Prisoners' Griewances, 39 GEo. WASH. L. REv. 175 (1970); Jacob, Prison Discipline and Inmate Rights, 5 Harv. Civ. Rights-Civ. Lib. L. Rev. 227 (1970); Turner, Establishing the Rule of Lau' in Prisons: A Manual for Prisoners' Rights Litigation, 23 Stas. L. REv. 473 (1971); Note, The Problems of Modern Penology: Prison Life and Prisoner Rights, 53 Iowi $\mathrm{L}$. Rev. 6'1 (1967); Note, The Right of Expression in Prison, supra noic 3; Notc, Constitutional Rights of Prisoners: The Developing Law, 110 U. PA. L. REv. 985 (1962); Note, Decency and Fairness: An Emerging Judicial Role in Prison Reform, 57 V. 1. REv. 841 (1971); Note, Prison Mail Censorship and the First Amendment, supra note 3: Note, Constitutional Limitations of the Conditions of Pretrial Detention, 79 YAlE L.J. 941 (1970); Note, Beyond the Ken of the Courts: A Critique of Judicial Refusal to Review the Complaints of Convicts, 72 YALE L.J. 506 (1963).

14. 378 U.S. 546 (1964) (per curiam).

15. Id. The decision held that an allegation that prison administrators vere interferring with the religious activities of Black Muslim prisoners in violation of the First and Fourteenth Amendments stated a cause of action under the Civil Rights Act, 42 U.S.C. $\$ \$ 1983,1985$ (1958).

16. For a general list of successful post-Cooper expression cases, see note 3 supra. The fate of the most recent cases involving prisoner allegations of First . Imendment violations has been mixed, reflecting continuing judicial uncertainty as to the rights of prisoners. See, e.g., Gray v. Creamer, 465 F.2d 179, 186 (3d Cir. 1972) (allegation that unlawful mail censorship violates prisoner's First and Fourteenth Amendment rights must be heard on the merits); Collins v. Schoonficld, 344 F. Supp. 237, 275-77 (D. .Id. 1972) (prison authorities cannot exercise absolute discretion in inspecting, censoring. and refusing to deliver inmate mail, but the court cannot say that any particular type 
enunciated a general First Amendment standard for prisoner expression. ${ }^{17}$

In the three recent cases, continuing judicial reluctance to apply full First Amendment protection to prisoner expression has led to the exploration of novel doctrinal terrain. Restrictions on inmate communication were there invalidated because they abridged a combination of the rights of inmates and those outside the prison with whom or by whom communication was sought. ${ }^{18}$ In Nolan $v$. Fitzpatrick, the First Circuit explicitly declined to hold that prisoners retain the First Amendment rights of ordinary citizens. ${ }^{10}$ Nevertheless, Judge Coffin struck down a flat ban on prisoner correspondence with newsmen "primarily" because "the condition of our prisons is an important matter of public policy." 20 The public policy relevance of prisoner correspondence was found to implicate the "right of the public to hear" which in turn "enhanced" expression rights of the prisoners. ${ }^{21}$ Because this duo of rights was entitled to traditional First Amendment protection, the court required the use of less drastic means ${ }^{22}$ to further the asserted

of mail censorship is completely proscribed by the Constitution). But see In re Hounshell, No. 7798 (San Luis Obispo County, Calif. Super. Ct., Aug. 10, 1972), I PRison L. Rirrk. 294 (1972) (inmates may be limited in the number of hard-cover books they can keep in their cell); Freeley v. Henderson, No. 16580 (N.D. Ga., June 29, 1972), 1 P'RISON l. RPTR. 270 (1972) (while the First Amendment prohibits a blanket denial of fcderal prisoner's request to prepare memoirs, diaries, or manuscripts, the prisoner may not publish such material if publication, in the warden's view, would lead to prison dis. ruptions) (dictum).

17. For the form such a doctrine might assume, see p. 1353 infra.

18. Before the three decisions, courts had generally ignored the effect of rules re. stricting prisoner communication on "listeners" rights. See, e.g., McDonough v. Director of Patuxent, 429 F.2d 1189 (4th Cir. 1970). In $M c D o n o u g h$, the Fourth Circuit decided that while an inmate had a right to correspond with Playboy for the purpose of obtaining assistance for a defective delinquency redetermination hoaring, prison officials could suppress prisoner correspondence whose "purpose . . was to effect pub. lication of a critique of the defective delinquency law and its implementation . . .." Id. at 1193. The court did not consider the potential value of such a critique to the readers of Playboy. See also Maas v. United States, 371 F.2d 348 (D.C. Cir. 1966) (prisoncr's manuscript dealing with organized crime, originally written at government re(uest, confiscated on the ground that publication would be detrimental to law enforcenent).

19. 451 F.2d 545, 547 (1st Cir. 1971).

20. Id. The court held that the prisoners could transmit to the press any letters concerning prison management, treatment of offenders, or personal grievances cxcept those which "(a) contain or concern contraband or (b) contain or concern any plan of escape or device for evading prison regtlations." Id. at 551 . Judge Coffin noted at the beginning of the opinion that the prisoner-plaintiffs had not asserted a "right to correspond with the news media about matters of public policy or personal affairs unrelated to the prisons." Id. at 546. This suggests that correspondence with newsmen not related to prison affairs could still be restricted. See also Conklin v. Hancock, $334 \mathrm{~F}$. Supp. 1119, 1122 (D.N.H. 1971) (Nolan does not extend protection to communication concerning matters unrelated to the prison) (dictum). The authority to determinc, in close cases, what did or did not relate to the prison would presumably rest with ad. ministrators. The validity of such a subject-matter based distinction has since become suspect. See pp. 1349-50 infra.

21. 451 F.2d at 548 .

22. Id. at 548, 551. For discussion of the less drastic means test, see United States v. O'Brien, 391 U.S. 367, 377 (1968); Note, Less Drastic Means and the First Amendment, 78 YaLe L.J. 464 (1969). 
state interests in prison security and discipline. ${ }^{23}$

In Washington Post Co. v. Kleindienst, ${ }^{2 t}$ the fact that non-inmate interests were at issue was even more obvious than in Nolan, since an absolute ban on interviews was challenged not by the prisoners, but by the newspaper which had been denied interviewing privileges." $=$ In this context, the court noted no fewer than three interests affected by the interview ban:

As this inquiry is pursued there is no need to differentiate between the rights of the press and the rights of prisoners. . . . News gathering and news dissemination cannot be disassociated under circumstances such as these where it is assumed there is a mutual desire to communicate and where, in the last analysis, the public right to be informed may well overshadow cither of the other two considerations. ${ }^{20}$

This amalgam of interests, the court believed, was deserving of full First Amendment protection. ${ }^{27}$ Finding that less drastic means could be employed to further the state interests of prison security and discipline, the court invalidated the interview ban. ${ }^{28}$

The same amalgam was invoked in Bumham $v$. Oswald ${ }^{20}$ against a rule forbidding press interviews with inmates where such interviews would adversely affect the "integrity" of the institution. ${ }^{30}$ Beginning with the proposition that "the right of an inmate to send letters to the press survives incarceration," the court reasoned that inmates must also

23. 451 F.2d at $548-49$.

24. Civil No. 467-72 (D.D.C., Apr. 5, 1972), 1 PRusos L. RmR. 141 (1972). After the Supreme Court decided Branzburg v. Hayes, 408 U.S. 665 (1972), it staycd the Washington Post decision, 406 U.S. 912 (1972), pending appeal. In its appeal of IWashington Post, the Government argued that Branzburg constituted a significant limitation on the protection afforded news gathering activities and obtained a remand of I'ashington Post for reconsideration in the light of Branzburg. Civil No. $72-1362$ (D.C. Cir., Sept. 6, 1972), 1 Prison L. RPTR. 337 (1972). On remand, the district court reaffirmed its original decision. Civil No. 467-72 (D.D.C., Dec. 19, 1972). See pp. 1352-53 infra. The Bureau of Prisons has appealed the second district court decision.

25. Ben Bagdikian, a Washington Post reporter, had unsuccessiully sought access to prisoners who had agreed to be interviewed at two federal institutions, Lewisburg and Danbury. He was denied permission by Norman Carlson, Dircetor of the United States Bureau of Prisons, who relied on a Bureau of Prisons Policy Statement of Feb. 1I, 1972, prohibiting all interviews of federal prisoners by newsmen. See note 11 supra. 26. Civil Action No. $467-72$ (D.D.C., Apr. 5, 1972) at 6, 1 Pruso: L. RrTr. at 142.

27. Id. at 8-9, 1 Prison L. RPrr. at 143 .

28. Id. For two prior cases rejecting the contention that restrictions on press interviews infringed prisoners' First Amendment rights, see Seale v. Manson, 326 F. Supp. 1375 (D. Conn. 1971) (rule requiring administrative approval of prisoner's request for press interview is reasonable and does not violate the First Amendment) and Smith $v$. Bounds (E.D.N.C., Mar. 10, 19\%2), 1 PrisoN L. Rrm. 144 (1972) (interview ban held within discretion of prison officials since prisoners had sufficient opportunity for contact with newsmen by means of correspondence). Seale and Smilh dilfer from Washington Post in that they involved only allegations of infringement of inmales' rights.

29. 342 F. Supp. 880 (W.D.N.Y. 1972).

30. Id. at 887 . 
have the right to have newsmen visitors under reasonable circumstances, apparently on the grounds that no compelling reason had been suggested for differentiating between the two forms of communication. ${ }^{11}$ This conclusion, the court argued, was "buttressed by a consideration of the rights of the newsmen . . . to gather information and to have access to news sources" as well as by the public's right to hear and be informed. ${ }^{32}$ Thus, having found a combination of interests worthy of First Amendment status, the court invalidated the prison's interview rules. $^{33}$

At first impression Nolan, Washington Post, and Burham all appear to fall squarely within the post-Cooper line of cases adding rights of access to newsmen as another step toward general First Amendment protection for prisoners. But, in fact, all three decisions declined to rest their holdings solely on prisoners' rights. ${ }^{34}$ Rather the protection of communication between press and prisoners was based on an amalgam of the prisoner's right to communicate, the press' right to gather news, and the public's right to know. ${ }^{35}$

For plaintiffs such a summing of rights may seem an attractive doctrine. ${ }^{36}$ Although post-Cooper courts have been increasingly willing to vindicate prisoners' First Amendment claims, in each case there has been a threshold question of whether the particular right asserted survived incarceration. ${ }^{37} \mathrm{But}$, once the rights of non-prisoners are invoked, the necessity for such an inquiry is largely obviated. A potential flaw in the amalgam doctrine, however, is that the interests it encompasses are perhaps less deserving of First Amendment protection

31. Id. at 885 .

32. Id. at $885-86$

33. Id. at 887 .

34. See pp. 1340-41 supra.

35. All three decisions relied on either a "public right to hear" or "public right to know." Washington Post and Burnham also relied on a distinct press right to gather news. Nolan did not consider the press right. See 451 F.2d at 547 n.2.

36. The fate of subsequent cases utilizing similar theories has been mixcd. See McDonnel v. Wolff, 342 F. Supp. 616, 624 (D. Iowa 1972) (ban on prisoner letters to news media whose violation is accompanied by severe punishment should be relaxed but it is unnecessary to decide whether such a ban is unconstitutional) (dictum). But see ScattleTacoma Newspaper Guild v. Daggett, Civil No. 9557 (D. Wash., May 6, 1972), 1 PRison L. RPTR. 229 (1972) (court may not order officials at a federal penitentiary to lift re. striction on press interviews of prisoners). For a case rejecting the notion that reporters have a right to gather news, and yet allowing prisoner interviews solely on the basis of the prisoner's right of expression, see Hillery v. Procunier, Civil No. C071-2150 SIW (N.D. Cal., Sept. 28, 1972). Hillery is of dubious precedential value becatisc it only reached the issue of prisoners' rights after mistakenly concluding that the Supreme Court in Branzburg v. Hayes, 408 U.S. 665 (1972), withdrew constitutional protection from reporters' news-gathering activities. See p. 1346 infra.

37. A "balancing" approach has often been utilized by post-Cooper courts to detcrmine which constitutional rights accompany a prisoner into incarceration. See, c.g., Walker v. Blackwell, 411 F.2d 23, 25 (5th Cir. 1969); Jackson v. Godwin, 400 F.2d 529 (5th Cir. 1969); Palmigiano v. Travisono, 317 F. Supp. 776, 786 (D.R.I. 1970). 
than was originally supposed. All three courts recognized the uncertain status of prisoner First Amendment claims and sought to avoid exclusive reliance on them. But they then relied on other rights, those of the press and public, whose status was equally uncertain.

At the time Nolan, Washington Post, and Burham were decided, for example, lower courts were in disagreement as to whether the right to gather news even existed. ${ }^{38}$ Although the Supreme Court had not considered the issue directly, in Zemel $v$. Rusk ${ }^{30}$ it did reject a claim that a ban on travel to Cuba violated the First Amendment right of an individual to acquire information. While that case involved individual information-gathering rather than an access claim by the press, Zemel holds at a minimum that not all attempts to acquire information are constitutionally protected. ${ }^{40}$

Unlike the right of the press to gather news, the public right to know had enjoyed affirmative recognition from the Supreme Court. In Red Lion Broadcasting Co. v. FCC,"1 the Court upheld the FCC's "fairness doctrine" as furthering "the right of the public to receive suitable access to social, political, esthetic, moral and other ideas." +2 In that context, the public right to know was an allocative concept requiring broadcasters to offer opportunities for a diversity of viewpoints. ${ }^{\text {i3 }} \mathrm{But}$ it is not immediately clear that the Red Lion right to know is the same right which figured in the prison cases. The uncertainty results from the fact that the term "public right to know" is subject to at least three different interpretations.

First, in perhaps its most popular sense, the public right to know may mean an affirmative government obligation to disclose information. ${ }^{\text {t4 }}$ This version of the right, which may be termed the government disclosure duty, is akin to the concept embodied in the Freedom of Infor-

38. Compare Caldwell v. United States, 434 F.2d 1081 (9th Cir. 1970), rev'd, 403 US. 665 (1972), and Schnell v. City of Chicago, 407 F.2d 1084 (7th Cir. 1969), utilh Tribune Review Publishing Co. v. Thomas, 254 F.2d 883, 884-85 (3d Cir. 1958). See Note, The Right of the Press to Gather News, 71 Colum. L. REv. 838, 848 (1971).

39. 381 U.S. 1 (1965).

40. The Court admitted that though the travel ban rendered "less than wholly free the flow of information concerning [Cuba]," id. at 16. it was not unconstitutional because "the right to speak and publish does not carry with it the unrestrained right to gather information." Id. at 17. While it has been suggested that the outcome of the case might have been different if the unsuccessful traveler had been a journalist rather than a private citizen, Note, The Right of the Press to Gather Neus, supra note 38, at 846 , Zemel offers little support for a reporter's constitutional right of access to news sources.

41. 395 U.S. 367 (1969).

42. Id. at 390 .

43. See id. at 380-90. See generally T. EMrerson, Tue Systesr of Freedom of Expression 656-67 (1970).

44. See generally H. L. Cross, Tine People's Rigir to kNow (1953); T. Eunson, The System of Freedom of Expression, supta note 43, at 672. 
mation Act ${ }^{i 5}$ which provides every citizen with access to unclassified government information. But in the absence of such a statutorily-created disclosure duty, no court has ever suggested that the First Amendment alone mandates the release of such information. In the three prison cases, there was no intent to invoke a government disclosure duty, although loose language in a subsequent Washington Post de. cision may come close. ${ }^{46}$

The second possible interpretation of the public right to know is that contained in Red Lion. In that case, the Court recognized that statesanctioned monopolies of radio and television frequencies inevitably restricted programming received by the public to that reflecting broadcasters' preferences. ${ }^{47}$ Because such a limitation on diversity resulted in part from government intervention, the Court viewed favorably a requirement that broadcasters allow equal broadcast time to speakers representing opposing points of view. ${ }^{48}$ But since air-time is limited, not all speakers or views could be accommodated. The "fairness doctrine" upheld by Red Lion thus obliges broadcasters to present only the views of responsible spokesmen on controversial issues, ${ }^{40}$ on the theory that these would best serve the public's interest in receiving diverse facts and opinions. This version, which may be termed the public right to hear, thus protects only a limited category of speech which meets administrative or judicial standards of relevance. Because each of the three prison cases invoked the public right to know after

45. 5 U.S.C. $\$ 552(1970)$.

46. The [United States] Bureau of Prisons .... has an obligation to lay open its activities to searching public scrutiny except to the extent that it can affirmativcly establish a compelling necessity to limit press access. There is an important and continuing discourse about our prisons, and the "right to receive information" necessary to convey developments to the public is within the scope of protections afforded by the First Amendment.

Civil No. $467-72$ (D.D.C., Dec. 19, 1972) at 3 (citation omitted). This language secms to imply that prison officials themselves have a duty to disclose news about internal prison affairs. But closer attention reveals that the court was not requiring the Burcau of Prisons to make public its official data but only removing a government-imposcd restriction on communication between willing inmate-speakers and reporters.

47. 395 U.S. at $388-89,392$

48. Id. at $390-91$.

49. 395 U.S. at 385 . Although Red Lion did not explicitly state that only "responsible" spokesmen were to be favored by application of the "fairness doctrine," the rule upheld by the decision was so limited. See, e.g., Note, Offensive Speech and the FCC, 79 YALE L.J. 1343,1348 (1970). The requirement that the view be on a "controversial" issuc clearly imposes a content-based restriction on the scope of the public right to hear doctrinc. This restriction raises the difficult question of what constitutes a "controversial" issuc. See, e.g., Friends of the Earth v. FCC, 449 F.2d 1164 (D.C. Cir. 1971) (commercials for high-powered cars and high-octane gasoline trigger the fairness doctrine); Green v. FCC, 447 F.2d 323, 331 (D.C. Cir. 1971) (military recruitment commercials do not trigger the "fairness doctrine" since "the undesirable features of military life have bcen displaycd in virtually every living room, frequently in living (or dying) color"); WCBS. $\Gamma V, 8$ F.C.C.2d 381 (1967), aff'd sub nom. Banzhaf v. FCC, 405 F.2d 1082 (D.C. Cir. 1968) ("fairness doctrine" held applicable to cigarette commercials). 
finding that prison affairs were vital matters of public policy, ${ }^{50}$ those decisions may be viewed as embracing this second version.

The third possible interpretation of the public right to know equates it with the private, personal right of all citizens to receive information directed to them. This concept, usually associated with Lamont $v$. Postmaster General, ${ }^{51}$ is designed to assure that citizens may hear speech addressed to them even though the speaker, through some quirk of status, may not himself be protected by the First Amendment.52 This right to receive information as upheld in Lamont resembles the public right to hear of Red Lion in its protection of communication between willing speakers and listeners, but differs in that it protects all speech, regardless of value or relevance. ${ }^{53}$ None of the prison cases, however, seems to involve this version, since, as previously suggested, each appears to invoke a right to hear stemming from the public policy content of prisoner-press communications. ${ }^{\text {st }}$

By eschewing Lamont's more prosaic version of the right to receive information in favor of Red Lion's content-oriented public right to hear, the three prison cases created an immediate doctrinal problem: No court had ever applied the Red Lion doctrine outside the broadcast context. Indeed, judicial recognition of content-related distinctions between different categories of speech had been explicitly rejected in a number of cases. ${ }^{55}$ Thus, as with the press right to gather news, the public right to know component of Washinglon Post, Nolan, and Burham was equally without direct precedent.

Such doubts have been amplified by two subsequent Supreme Court decisions. Branzburg $v$. Hayes ${ }^{50}$ further undercuts the already uncertain notion that the First Amendment confers a special right of the press to gather news, and Kleindienst $v$. Mandel ${ }^{57}$ calls into question the under-

50. Civil No. 467-72 (D.D.C., Apr. 5, 1972) at 4, 1 Prison L. RPTR. 141 (1972); 342 F. Supp. 880 (W.D.N.Y. 1971); 451 F.2d 545, 547 (1st Cir. 1971).

51. 381 U.S. 301 (1965).

52. In Lamont, the rights of American addressees of communist propaganda mailed from abroad were entitled to constitutional protection, even though the alien writers themselves might have been excluded from First Amendment coverage. Id. at 307.03.

53. Lamont did not explicitly state that it protects receipt of all speech regardless of social worth, but such a holding is implied in its rejection of the authority of ad. ministrators to "appraise" the mailed material. 381 U.S. at 306 . A later case, Stanley v. Georgia, 394 U.S. 557 (1969), explicitly declares that the individual right to receive information does not involve any evaluation of the "social vorth" of the material to be received. Id. at 564 . But see Note, Still Afore Ado About Dirty Books (and Pictures): Stanley, Reidel and Thirty-seven Photographs, 81 YALE L.J. 309 (1971).

54. See p. 1344 supra.

55. See, e.g., New York Times v. Sullivan, 376 U.S. 254, 269.70 (1964); Kingsley Pictures Corp. v. Regents, 360 U.S. 684, 689 (1959); Winters v. New York, 333 U.S. 507,510 (1948); Thomas v. Collins, 323 U.S. 516, 537 (1945).

56. 408 U.S. 665 (1972).

57. 408 U.S. 753 (1972). 
lying validity of the public right to hear, at least in non-broadcast contexts.

\section{The Right to Gather News After Branzburg}

Branzburg did not involve news-gathering in the prison context but rather the claim that the First Amendment afforded newsmen a privilege to withhold the content of confidential interviews from state and federal grand juries. ${ }^{58}$ Though conceding that requiring such testimony would impede news-gathering ${ }^{50}$ by inhibiting confidential sources, ${ }^{, 0}$ the Court nevertheless rejected the privilege claim, holding that the "public interest in law enforcement and in ensuring effective grand jury proceedings" was sufficient to "override the consequential, but uncertain, burden on news gathering." 61 Central to this holding was the finding that the newsmen had failed to demonstrate that the testimony would result in "a significant constriction of the flow of the news to the public." 62

But this denial of privilege was not predicated on the absence of a right to gather news; indeed, its existence was specifically acknowledged. ${ }^{63}$ What the Court did deny was that requiring reporters to testify would normally result in an impermissible inhibition or chilling of the exercise of that right with a consequential diminution in news flow. ${ }^{64} \mathrm{It}$ is odd, however, that the plurality could so firmly reject the

58. 408 U.S. at 690 . Branzburg was a consolidation of four state and federal court cases. The first two were Branzburg v. Pound, 461 S.W.2d 345 (Ky. 1971), and Branzburg v. Meigs, an unreported decision of the Kentucky Court of Appeals. They involved con. tentions by Branzburg, a reporter for the Louisville Courier-Journal, that he was privileged to withhold from state grand juries information acquired from confidential sources about manufacture, sale, and use of hashish and marijuana. 408 U.S. at 667.71. The third, In re Pappas, 358 Mass. 604, 266 N.E.2d 297 (1971), involved a state court effort by Pappas, a reporter for a New Bedford, Mass., tclevision station, to withhold confidential information acquired during a three-hour stay inside the New Bedford headquarters of the Black Panther Party. 408 U.S. at 672-75. The fourth, Unitcd States v. Caldwell, 434 F.2d 1081 (9th Cir. 1970), arose from the efforts of Caldwell, a New York Times reporter, to withhold confidential information about the aims, purposes, and activities of the Black Panther Party from a federal grand jury. 408 U.S. at 675.79. Statc courts had rejected the claims of Branzburg, id. at 669-71, and Pappas, id. at 678.75. but the Ninth Circuit had held that the First Amendment afforded Caldwell a privilege not only to withhold testimony absent a compelling state interest but also to refuse grand jury attendance in the absence of any special necessity. Id. at 679. The Supreme Court affirmed the decisions in Branzburg and Pappas and reversed in Caldwell. Id. at 708.09.

59. Id. at 690 .

60. Id. at 693 .

61. Id. at 690 .

62. Id. at 693 .

63. The Court emphasized that its decision should not be interpreted as implying "that news gathering does not qualify for First Amendment protection; without some protection for seeking out the news, frecdom of the press could be cviscerated." Id. at 681 .

64. Id. at $681,690-95$. The standard of proof established by Branzburg may well in. sure that the news-gathering right will rarely prevail over state practices which are 
claim that the news-gathering right had been inhibited without clearly resolving the prior question of what that right was.

Branzburg's ambiguity results in part because what Justice White terms the "right to gather news" is subject to two possible interpretations. In an extensive discussion of its scope, he describes it as a "fundamental personal right ... which is not confined to newspapers and periodicals [but which] necessarily embraces . . . every sort of publication which affords a vehicle of information and opinion."vs So defined, the right protects reporters for unorthodox publications and even individual pamphleteers to the same degree it protects accredited representatives of the traditional news media. While not reading out a requirement that the news-gathering right be connected with some form of "press" activity, such a broad definition tends to trivialize the requirement and transmute the press right into an individual right nearly identical to Lamont's right to receive information. ${ }^{.8}$ In essence,

alleged to indirectly inhibit its exercise since, as Justice Stewart's dissent notes, "[t] he impairment of the flow of news cannot ... be proved with scientific precision, as the Court seems to demand." Id. at 733. The plurality's proof requirement scens to be novel in the First Amendment area. Justice Stewart noted that prior cases had not required that inhibition or "chilling effect" be objectively demonstrated. Id. at 733-34. Such a demonstration would obviously be rather difficult, as Justice Stcwart's diesent suggests. Would the plurality, for example, require evidence that the number of vords devoted to a category of news in a sampling of media had declined following the initiation of a "chilling" practice by the government? The value, and even availability. of such evidence seems doubtful. If it were a long-standing practice-c.s., requiring reporters to testify about confidential news sources before grand juries-a "control sample" indicating the quantity of news in the absence of the practice might be unasailable. Even if the practice had been recently initiated, the import of a showing of quantitative diminishment in news flow would undoubtedly be ambiguous. Other factors-including that always intangible concept, newsworthiness-might explain the decrease in coverage of a particular subject.

65. Id. at 704 , quoting from Lovell v. Griffin, 303 U.S. 444. 450, 452 (1938).

66. See p. 1345 supra. On their face, the rights differ: The right to hear pro. tects the simple receipt of information, while the right to gather new's protects acquisition of information with a view towards its dissemination. While the rights may indeed be distinguishable in active/passive terms, further meaninglul distinctions are nearly impossible to make. Both rights protect communication between a willing speaker and listener. See p. 1351 infra. Some indication that information which is sought will be "disseminated" may be a prerequisite to protection under the news-gathering right, but the requirement of such a showing is likely to be pro forma. Under Branzburg, courts would apparently be forbidden to inquire into the genuineness of the news dissemination purpose:

a [testimonial] privilege might be claimed by groups that set up newspapers in order to engage in criminal activity and to therefore be insulated from grand jury inquiry . . . . It might appear that such "sham" newspapers would be easily" distinguishable, yet the First Amendment ordinarily prohibits courts from inquiring into the content of expression .... and protects specch and publications regardless of their motivation, orthodoxy, truthfulness, timeliness, or taste . . . By alfording a privilege to some organs of communication but not to others, courts would inevitably be discriminating on the basis of content.

Id. at 705 n.40. If courts may not distinguish between "sham" and genuine assertions of the news-gathering right, then all that remains to separate it from the right to receive information is its active character, and perhaps a vestigial formal requirement that infringement of freedom of press be alleged. But see Note, Reporters and Their Sources: The Constitutional Right to a Confidential Relationship, 80 YALE L.]. 317 (1970).

The right to gather news might also be asserted in an attempt to force the government 
this interpretation of Branzburg collapses freedom of the press into freedom of speech with regard to the constitutional protection afforded information acquisition.

A second construction of Branzburg's news-gathering right emerges from another portion of the opinion where Justice White required proof of the effects of inhibition by a showing "that there would be a significant constriction of the flow of news to the public."07 By requiring such proof, Branzburg here appears to transform the right to gather news into a right which protects only activity demonstrably contributing to the aggregate amount of information reaching the public. It would not protect news gathering which, in objective terms, would contribute little or nothing to the general level of public information. So defined, the right would primarily shield the news gathering of traditional news organizations with large readerships since any inhibition of their news gathering would have a much greater impact on the flow of news than similar restrictions on pamphleteers or underground newspapers. ${ }^{68}$

Under either interpretation, however, Branzburg's recognition of a special reporter's right to gather news seems largely gratuitous. Under the first interpretation, the right recognized is only an analogue of the long-recognized First Amendment right of every individual to receive information and ideas. Under the second interpretation, a privilege of somewhat greater content may exist, but it is limited primarily to large news organizations. Moreover, by shifting focus from the rights of individual reporters to the interest of the general public in receiving an adequate flow of news, this latter version of the right to gather news becomes a derivative right which can be asserted only when it furthers the primary right of the public to hear. ${ }^{.0}$ Yet even this second-class status for the right to gather news is problematic in view of dicta in

to reveal information it preferred to withhold. Language in Branzburg indicates such attempts would fail, since the press has no greater right to such information than do ordinary citizens. Of course, if the government had a duty to disclose certain information to ordinary citizens, then it would seem to have an equal duty to disclose it to news. men. See 408 U.S. at $684-85$. Private citizens would seem to be generally protected agalinst press efforts to force disclosure of information by elementary privacy consiclerations. See Washington Post Co. v. Kleindienst, Civil No. 467.72 (D.D.C., Apr. 5, 1972) at 8, 1 Prison L. RPrr. 141 (1972).

67. 408 U.S. at 693 (emphasis added).

68. For a speculative discussion of the implications of Branzburg for news gathering by the "underground press," see Comment, Has Branzburg Buried the Underground Press?, 8 Harv. Civ. Righrs-Civ. LiB. L. Rev. 181 (1973).

69. The interest of the public in receiving an adequate flow of news referred to in Branzburg is conceptually equivalent to the public right to hear doctrine of Red Lion. To maintain the distinctions developed among various interpretations of the "public right to know," the term "public right to hear" has been substituted for Branzburg's terminology. 
Kleindienst $v$. Mandel, ${ }^{70}$ a companion case to Branzburg, which undermine the very foundations of the public right to hear doctrine.

\section{The Public Right to Hear After Mandel}

In Mandel the Court refused to overturn the denial of a visitor's visa to a Belgian Marxist professor on the ground that Congress, and by delegation, the Executive, possessed a plenary power to exclude aliens without judicial review. ${ }^{71}$ But having thus disposed of the immediate problem before it, the Court then turned to what it apparently viewed as a more interesting issue: plaintiff's assertion that such exclusion infringed the rights of American academics to hear Mandel's speeches. ${ }^{72}$ Treating that First Amendment claim as if on the merits, the majority argued that if it were to balance the government's interest in excluding aliens against the alleged public right to hear them, one of two results would ensue. Either every claim for a visa would prevail, since every excluded alien presumably has at least one potential listener, and the exclusion law would be rendered a "nullity," or courts would be required to "weigh the strength of the audience's interest against that of the government . . . according to some as yet undetermined standard."73 Such a balancing test would, however, entail the "obvious dangers" of evaluating the audience's interests "on the basis of factors such as the size of the audience or the probity of the speaker's ideas." 74

This latter result was, in the Court's view, as "unsatisfactory" as the former: ${ }^{75}$ Regulation of communication between willing speakers and listeners could not be based on content or audience status factors. Since content-related factors such as relevance are critical to assertions of the

70. 408 U.S. 753 (1972).

71. Id. at $765-67,769-70$.

72. $I d$. at $768-69$.

73. Id.

74. Id. at 769. The Court has traditionally been loath to inquire into the content of expression. See note 55 supra. It has shed its reluctance in the obscenity field, but it did so there on the ground that obscenity is not protected by the First Amendment. See, e.g., Roth v. United States, 354 U.S. 476,489 (1957).

The concept that First Amendment claims may not be ranked according to the number of persons asserting protection is more novel, and on its face, potentially inequitable. Refusal to "sum" the rights of hearers in effect reduces the "rights to hear" of a large group of persons into a unitary right no more potent than the right of a single individual asserting a potentially competing First Amendment claim. This result is superficially at odds with the notion that the right to hear of each individual qua individual is equal. The "no summing" rule may, however, gain tangential support from decisions in the press context which have established that reporters representing media with large readerships enjoy no greater protection of the free press clause than individuals who disseminate news to much smaller audiences. See, e.g., Lovell v. Griffin, 303 U.S. 444, 450,452 (1938).

75. 408 U.S. at 768-69. 
public right to hear, ${ }^{76} \mathrm{Mandel}$ in effect, signals that this doctrine will not be extended beyond the limited-channel broadcast context of Red Lion.

Disapproval of the conceptual underpinning of the public right to hear does not, of course, withdraw First Amendment protection from listeners. Mandel explicitly reaffirms the third version of the public right to know, the "right to receive information and ideas." 77 Under that doctrine, every individual has a right to hear any speech directed to him, even though the speaker may not enjoy First Amendment protection. Thus if a plenary power had not been at stake in Mandel, ${ }^{78}$ then limitations on the right to receive information resulting from enforcement of the alien exclusion law could have been imposed only after the requisite "balancing" of classic First Amendment decisions, ${ }^{79}$ coupled with other considerations such as less drastic means. ${ }^{80} \mathrm{Mandel}$ merely rejects the proposition that the balance be struck more favorably for more "valuable" speech or larger groups of listeners. Except for the limited Red Lion exception, the public right to hear thus becomes no greater than every individual's right to receive information.

\section{Nolan, Washington Post, and Burnham After Branzburg and Mandel}

Because the state interests at stake in inmate cases are so different from those encountered in Branzburg and Mandel, the two decisions are obviously not directly controlling in prison contexts. ${ }^{81}$ Yet on a more abstract level, Branzburg and Mandel do concern communication rights among prisoners, press, and public. Although they are not directly relevant insofar as they deal with the manner in which balances

76. See pp. 1344.45 supra.

77. 408 U.S. at 762-64.

78. The Court might have proceeded beyond the plenary power issue simply by distinguishing prior alien exclusion cases on the grounds that none involved the rights of American citizens. This approach, suggested by Justice Marshall's dissent, id. at 783, would have made it necessary to balance government interests in exclusion against the First Amendment right to hear.

79. If the government measure were characterized as a direct restriction on the enjoyment of the First Amendment right, as Justice Marshall's dissent suggests, id. at 781, then the government would have the burden of showing that the information flow constituted incitement likely to lead to imminent lawless action. See, e.g., Brandenburg v. Ohio, 395 U.S. $444,447-49$ (1969). Even if the restriction were characterized as furthering a substantial interest unrelated to speech, the government would still have the burden of showing that no less drastic means were available. See note 22 supra.

80. See note 22 supra.

81. The increasing success of suits by prisoners alleging expression infringement indicates that courts are by and large unwilling to accord the same deference to state interests in effective prison administration as the Supreme Court did to grand jury functioning in Branzburg and alien exclusion in Mandel. See cases cited in notes 3 \& 16 supra. 
are to be struck against competing state interests, they do define the status and scope of rights which make up the First Amendment arm of such balances.

On this level, the ultimate effect of Branzburg and Mandel is to collapse the news-gathering right and the public right to know relied on by the prison decisions into rights possessed by every individual regardless of "press status" in its traditional sense. Branzburg's analysis of the right to gather news is ambiguous: news acquisition may enjoy protection not only under the rubric of the right of every citizen to acquire information, but also derivatively, insofar as it furthers the public's right to be informed. Yet Mandel suggests that any increment to the individual news-gathering right from a public right to hear is illusory since assertions of a right to hear do not gain additional priority according to the number of hearers or the value of the message. ${ }^{82}$ Thus a reporter's assertion of a public right to hear on behalf of his readership can be no more than an assertion of his own right to receive information. Similarly, claims of a news-gathering right are equivalent to those of ordinary citizens engaged in any information-acquisition for the purpose of further dissemination.

The two rights which emerge from Branzburg and Mandel are nearly identical. The news-gathering right protects communication initiated by persons seeking to receive information, while the right to hear, in contrast, covers communication initiated by speakers. However, in both instances, the rights function to protect a flow of information from speakers to listeners. Since the rights are in reality merely active and passive versions of the individual's right to receive communication, ${ }^{83}$ they can scarcely "enhance" one another. Thus, in each of the prison cases, only one right, in addition to the prisoners' rights of expression, was implicated: in Nolan and Burham, the right to hear, since there prisoners sought communication; ${ }^{84}$ in ITashinglon Post, the right to gather news, since there reporters were the initiators. ${ }^{85}$

Restructuring the doctrinal foundation of the prison cases to conform with Branzburg and MIandel need not, however, vitiate their holdings. Invoking the individual right to hear would have supported disapproval of the letter and interview bans in Nolan and Burnham. Because the right has First Amendment status, it prevails over all but

82. 408 U.S. 753, 769 (19'72).

83. The active/passive distinction relates only to the manner in which communication is initiated. Thereafter, the purpose of both rights is to protect the same flow of information from news source to listener. See note 66 supra.

84. 451 F.2d 545, 546 (Ist Cir. 1971); 342 F. Supp. 880, $882-83$ (W.D.N.Y. 1972).

85. Civil No. $467-72$ (D.D.C., Apr. 5, 1972) at 1, I Prison L. Rrm. 141 (1972). 
compelling state interests just as did the amalgam of rights cited in those cases. ${ }^{86}$ To the extent that a prison could legitimately insist that the number of letters or interviews be restricted, the prisoner himself, by allocating his quota of letters or interview requests to those he prefers, would determine whose right to hear would be vindicated.

Similarly, the right to gather news as it emerges from Branzburg would still justify the outcome in Washington Post. Since the restriction on news gathering there was direct, unlike the indirect effect alleged in Branzburg, ${ }^{87}$ proof of a causal link between the state practice and the resulting "inhibition" on the flow of news would be irrelevant. ${ }^{88}$ Even though it is reduced to individual status, the news-gathering right is still entitled to First Amendment protection ${ }^{80}$ and would thus again prevail absent state interests more significant than those in Washington Post. Restrictions on the number of interviews might, of course, be necessary if more reporters sought interviews than could be accommodated, ${ }^{00}$ but here again there is little need for a judicial allocation of access opportunities. The prisoner himself has a privacy right $n o t$ to be interviewed ${ }^{91}$ and can thus exclude interviewers, largely eliminating the need for any judicial intervention.

In fact, the second Washington Post opinion, ${ }^{03}$ rendered after a remand for reconsideration in the light of Branzburg, ${ }^{94}$ based its holding

86. In Nolan, the result of using the individual right to hear doctrine might have been even more favorable to prisoners and press listeners. While the "public right to hear" doctrine protected only inmate correspondence relating to prison affairs, 451 F.2d at 546, the individual right to hear protects all communication directed to a listener, regardless of its content. See note 20 supra.

87. See p. 1346 supra.

88. Despite this crucial distinction, the second Washington Post opinion apparcntly felt obliged to demonstrate that the Branzburg standard of proof on the probability of news flow diminishment had been met by finding that "the sources of news are solely in the prisons. No alternative satisfactory sources are available and the press claims its proper right of access." Civil No. $467-72$ (D.D.C., Dec. 19, 1972) at 6.

89. Branzburg's specific recognition of the existence of a First Amendment right to gather news, 408 U.S. at 681 , may cast doubt on the continuing validity of the Court's refusal in Zemel v. Rusk, 381 U.S. 1, 16 (1965), to accord First Amendment protection to information acquisition. The cases are distinguishable, though, in that Zemel In. volved a restriction on travel to a foreign country. Id. at 15.16.

The issue of Zemel's continuing validity aside, Branzburg, at the very least, requires some protection for news gathering. While the degrec of protection allowed is not clear, the opinion suggests that direct restrictions on news gathering are to be tested against traditional First Amendment standards. 408 U.S. at 700-01. Indirect restrictions, however, are subject only to an ambiguous "constriction in flow of news" test-unique in recent First Amendment decisions. See note 64 supra.

90. See, e.g., Burnham v. Oswald, 342 F. Supp. 880 (W.D.N.Y. 1972).

91. See, e.g., Washington Post Co. v. Kleindienst, Civil No. 467.72 (D.D.C., Apr. 5, 1972) at 3, 1 PRISON L. RPTR. 141 (1972).

92. If an inmate indicated he was willing to be interviewed by any newsman but had no basis for choosing among them, a court might resolve access problems by ap. plication of a "neutral" access-rationing scheme, such as "first comc, first scrved" or random selection.

93. Civil No. 467-72 (D.D.C., Dec. 19, 1972).

94. Civil No. 72-1362 (D.C. Cir., Sept. 6, 1972), 1 Prison L. Rirr. 337 (1972). 
on an individual news-gathering right. Shifting conceptual grounds, the court reaffirmed its disapproval of the interview ban, not on the theory that special reporters' rights were at stake, but rather because members of the public had a right of access which protected reporters as much as anyone else. ${ }^{95}$ Such emphasis on the individual's right to receive information scarcely constitutes new First Amendment theory. ${ }^{96}$ Indeed, if the Amendment protects the communication of propaganda from foreign communists ${ }^{27}$ or salacious books from foreign publishers, ${ }^{98}$ surely it should operate with at least equal vigor to protect communication between American prisoners and the public. The prison cases thus correct a long period of judicial oversight ${ }^{\text {to }}$ by effectively extending the right to hear to the prison context, not just for reporters but for every individual. A second and perhaps less commendable result of application of the individual right to hear to the prison context is to render the constitutional status of prisoner expression irrelevant, since the right to hear, standing alone, mandates the full application of First Amendment standards.

Thus, while vindication of the individual right to hear is undoubtedly a practical success for those asserting prisoner access rights, ${ }^{100}$ it leaves unresolved the question of what First Amendment rights prisoners themselves ought to enjoy. ${ }^{101} \mathrm{But}$ if prisoners were generally accorded the First Amendment rights of ordinary citizens, there would be no need for right to hear doctrines, since prisoners' rights would always be sufficient to invoke the First Amendment. This would not, however, mean that all speech activities would be protected inside a prison: Expression could still be legitimately curtailed where necessary to further the special state interests involved in corrections, so long as no less drastic means were available. ${ }^{102}$

95. Civil No. 467-72 (D.D.C., Dec. 19, 1972) at 5.6.

96. See p. 1345 supra.

97. Lamont v. Postmaster General, 381 U.S. 301 (1965).

98. United States v. Eighteen Packages of Magazines, 238 F. Supp. 816 (N.D. Cal. 1964).

99. See note 18 supra.

100. See p. 1342 supra.

101. Nolan, Washington Post, and Burnham, for cxample, cannot eren support the proposition that prisoners themselves enjoy a right of access to newsmen which independently merits First Amendment protection since in cach decision the constitutional protection of communication between newsmen and inmates was based on the aggregate effect of an amalgam of prisoners' and non-prisoners' rights. See p. 1342 supra. 102. The outcome of the less drastic means test in the prison context might vicll differ in many instances from the result in the "outside" world since peculiar state interests, such as security and rehabilitation, are at stake. For example, prison administrators have an obvious interest in preventing the use of the mails to transmit escape plans. Inspection and interception of incoming and outgoing mail containing such plans may well be the least drastic means by which that state interest can be adcquately furthered. Such screening would probably thus meet First Amendment standards, though it vould certainly be unconstitutional if applied outside the prison where no special security interests are at stake. See generally Note, Prison Mail Censorship and the First Amendment, 81 YALE L.J. 87, 94-104 (1971). 


\section{Conclusion}

The task of extending full expression rights to inmates belongs to future courts. Nolan, Washington Post and Burnham, unwilling to break with the notion that prisoners do not enjoy the full protection of the Constitution, ${ }^{103}$ compromised by extending protection on the basis of a combination of prisoner and non-prisoner rights. Though achieving results of practical benefit to prisoners and public alike, the decisions fail to take the final steps in the journey toward full recognition of prisoners' First Amendment rights begun by Cooper v. Pale ${ }^{104}$ in 1964.

103. Nolan v. Fitzpatrick, 451 F.2d 545, 547 (1st Cir. 1971); Washington Post Co. v. Kleindienst, Civil No. 467-72 (D.D.C., Apr. 5, 1972) at 3, 1 l'kison L. Rirk. 141 (1972); Burnham v. Oswald, 342 F. Supp. 880, 884 (W.D.N.Y. 1972).

104. 378 U.S. 546 (1964) (per curiam). 